\title{
FAKTOR-FAKTOR YANG BERHUBUNGAN DENGAN KEAKTIFAN KADER DALAM PELAKSANAAN PROGRAM DESA SIAGA DI DESA TANJUNG MEDANG WILAYAH KERJA PUSKESMAS RUPAT UTARA KABUPATEN BENGKALIS TAHUN 2017
}

\author{
Muhammad Nurman \\ Dosen FIK Universitas Pahlawan Tuanku Tambusai, Riau, Indonesia \\ muhammadnurman1977@yahoo.com
}

\begin{abstract}
ABSTRAK
Pelaksanaan Program Desa Siaga sebagai program Desa yang berbasis pemberdayaan masyarakat. Salah satu keberhasilan Desa Siaga adalah keaktifan para kader. Kader dianggap paling dekat dengan masyarakat itu sendiri. Data Desa yang ada di Kota Bengkalis terdapat 103 Desa dan 20 Desa sudah menjadi Desa Siaga yang salah satunya adalah Desa Tanjung Medang yang belum berjalan dengan aktif.

Penelitian ini bertujuan untuk mengetahui faktor-faktor yang berhubungan dengan keaktifan kader dalam pelaksanaan Desa Siaga di Desa Tanjung Medang Wilayah Kerja Puskesmas Rupat Utara.

Desain penelitian ini adalah survei analitik dengan pendekatan cross sectional. Populasi penelitian ini adalah seluruh kader Desa Siaga di Desa Tanjung Medang berjumlah 30 kader. Sampel penelitian ini adalah seluruh jumlah populasi yaitu 30 responden. Teknik pengambilan sampel secara Total Sampling. Analisa yang dilakukan adalah analisa univariat dan bivariat.

Hasil penelitian didapatkan Adanya hubungan bermakna antara faktor pengetahuan kader (nilai $p$ value 0,000), ketersediaan dana (nilai $p$ value 0,05) dan dukungan masyarakat (nilai $p$ value 0,010) dengan keaktifan kader dalam pelakasanaan program Desa Siaga di Desa Tanjung Medang Wilayah Kerja Puskesmas Rupat Utara Kabupaten Bengkalis tahun 2016. Diharapkan kepada pihak Puskesmas lebih maksimal lagi melakukan evaluasi terhadap pelaksanaan program Desa Siaga ini dan bagi pihak Desa disarankan dapat membuat kebijakan yang senantiasa mendukung dan berperan aktif dalam pelaksanaan program Desa Siaga di Desa Tanjung Medang wilayah kerja Puskesmas Rupat Utara.
\end{abstract}

Daftar Bacaan : $26(1988-2015)$

Kata Kunci : Keaktifan Kader, Desa Siaga 


\section{LATAR BELAKANG}

Pembangunan kesehatan merupakan suatu investasi untuk peningkatan kualitas Sumber Daya Manusia (SDM) dalam mendukung percepatan pembangunan nasional (Depkes RI, 2009). Pelayanan kesehatan dasar menjadi fokus utama upaya bidang kesehatan Indonesia untuk mencapai target Millenium Development Goals (MDGs) 2015 yaitu Indonesia dapat menekan angka kematian ibu menjadi 102/ 100.000 kelahiran hidup dan menekan angka kematian bayi menjadi 15/ 1000 kelahiran hidup. Tingginya angka kematian di Indonesia, terutama kematian ibu yaitu sebesar 226/ 100.000 kelahiran hidup, selanjutnya untuk angka kematian bayi sebesar 26/ 1000 kelahiran hidup, menunjukkan masih rendahnya kualitas pelayanan kesehatan di Indonesia (Depkes RI, 2009).

Departemen kesehatan RI memiliki visi "Masyarakat Yang Mandiri Untuk Hidup Sehat" dan misi " Membuat Rakyat Sehat". Visi dan Misi Dep Kes RI tersebut membuat propinsi

Riau khususnya Kabupaten Bengkalis untuk lebih meningkatkan kesejahteraan masyarakatnya terutama dalam hal kesehatan, yaitu untuk membentuk Desa Siaga sesuai wewenang dan tanggung jawab masing-masing kota atau kabupaten. Kegiatan desa siaga seluruh kota atau kabupaten di Indonesia, mengacu pada Standar Pelayanan Minimal (SPM), yang mentargetkan $80 \%$ Desa Siaga telah aktif pada tahun 2015 (Menkes RI,2008).

Desa Siaga merupakan salah satu sasaran dari tiga sasaran Grand Strategy Departemen Kesehatan, yang menyebutkan bahwa pada akhir tahun 2015, seluruh desa telah menjadi Desa siaga, yaitu desa yang memiliki kesiapan sumber daya serta kemauan dan kemampuan untuk mencegah dan mengatasi masalah masalah kesehatan, bencana dan kegawatdaruratan kesehatan secara mandiri (Supariyanto, 2010).

Salah satu kunci keberhasilan dan kelestarian desa siaga adalah keaktifan para kader. Kader dianggap paling dekat dengan masyarakat itu sendiri, Depertemen Kesehatan membuat program pelatihan untuk kader kesehatan agar kader-kader kesehatan desa siaga nantinya mempunyai pengetahuan yang lebih, dengan harapan kader dapat menggerakkan dan memberdayakan masyarakat agar tercipta masyarakat yang mandiri untuk hidup terutama pada kesehatan ibu dan anak guna mencapai penurunan AKI dan AKB di Indonesia (Hidayati, 2011).

Kinerja kader dalam penampilan hasil kerja personal baik kuantitas maupun kualitas dalam suatu organisasi. Kinerja dapat merupakan penampilan individu maupun kelompok kerja personal. Kinerja pada desa siaga dapat dihubungkan dengan beberapa faktor antara lain tingkat pendidikan, tingkat pengetahuan serta pengalaman dari personal masingmasing (Ilyas, 2002). 
Di Propinsi Riau terdapat 12 kabupaten, salah satunya adalah kabupaten Bengkalis. Kabupaten Bengkalis mempunyai 8 kecamatan dan 103 desa. 20 desa diantaranya sudah menjadi desa siaga $(20,6 \%)$, salah satu desa yang dalam pembinaan Desa Siaga adalah Desa Tanjung Medang Kecamatan Rupat Utara. Angka Kematian Ibu (AKI) dan Angka Kematian Bayi (AKB) akibat hamil, bersalin, dan nifas di Kecamatan Rupat Utara pada tahun 2014 mencapai 0/100.000 kelahiran hidup dan Angka Kematian Bayi 4/1000 kelahiran hidup, sedangkan pada tahun 2015 angka kematian ibu tetap 0/100.000 kelahiran hidup, tetapi angka kematian bayi menjadi meningkat menjadi $\quad 13 / 1000$ kelahiran hidup; selanjutnya pada tahun 2016 dari bulan Januari Oktober AKI sementara yang diperoleh yaitu $\quad 0 / 100.000$

kelahiran hidup dan angka kematian bayi hasil sementara 5/1000 kelahiran hidup. Keadaan tersebut mendorong Kecamatan Rupat Utara untuk memelihara dan meningkatkan pelaksanaan program Desa Siaga. Kecamatan Rupat Utara memiliki 5 Desa, 1 diantaranya merupakan Desa Tanjung Medang (Dinkes Kab. Bengkalis,2015).

Berdasarkan survey awal yang dilakukan wawancara terhadap 10 orang Kader Desa Siaga yang ada di Desa Tanjung Medang, didapatkan hasil bahwa 8 orang mengatakan kurang memahami tentang Program pelaksanaan Desa Siaga, seperti waktu ditanyakan apa saja yang menjadi tugas kader, para kader tersebut tidak bisa menjelaskannya dengan baik dan waktu ditanyakan pernah memberikan penyuluhan kesehatan kepada masyarakat terkait dengan masalah kesehatan dimasyarakat, kader tersebut mengatakan belum pernah dilakukan, dengan alasan belum pernah mendapatkan pelatihan bagaimana cara memberikan penyuluhan kesehatan. Namun demikian ada 2 orang yang memahami Program Desa Siaga tersebut dan juga terlibat memberikan penyuluhan kesehatan kepada masyarakat terkait dengan masalah kesehatannya. Selain dari pengetahuan kader yang kurang tentang program Desa Siaga, kader juga mengatakan program desa siaga kurang berjalan dengan baik karena kurangnya dukungan dari masyarakat dan keterbatasan dana untuk digunakan dalam pelaksanaan Program Desa Siaga baik dari Pemerintah Desa maupun Pemerintah Daerah.

Pelaksanaan programprogram Desa Siaga memerlukan kerjasama dari beberapa pihak terkait diantaranya perangkat desa, tokoh masyarakat, kader kesehatan, pemuda, LSM, dan seluruh warga masyarakat pada umumnya. (Syafrudin, Hamidah, 2009). Kader kesehatan merupakan pelaksana program Desa Siaga. Kader kesehatan yang aktif melaksanakan tugasnya dengan baik dapat menjadi salah satu indikator keberhasilan pengembangan program Desa Siaga (Syafrudin, Hamidah, 2009).

Kader mempunyai 6 peran dan fungsi sebagai pengembang desa siaga, yaitu: (1) Membantu tenaga kesehatan dalam mengelola desa 
siaga melalui kegiatan Usaha Kesehatan Berbasis Masyarakat (UKBM) seperti posyandu, poskesdes, (2) Memantau kegiatan dan evaluasi desa siaga seperti mengisi Register Ibu dan Anak, mengisi KMS, (3) Membantu mengembangkan dan mengelola UKBM selain posyandu, (4) Membantu mengidentifikasi dan melaporkan kejadian di masyarakat yang dapat berdampak kepada masyarakat, (5) Membantu dan memberikan pemecahan masalah kesehatan yang sederhana kepada masyarakat, (6) Mempersiapkan masyarakat dalam menghadapi kedaruratan kesehatan dan penanggulangan bencana (Depkes RI, 2009).

\section{Puskesmas Rupat Utara} merupakan salah satu puskesmas yang berada dalam wilayah kerja Dinas Kesehatan Kabupaten Bengkalis. Puskesmas Rupat Utara membina 5 Desa yang masingmasing telah dibentuk menjadi desa siaga mulai tahun 2013. Semenjak dibentuk dari 5 Desa ini satupun belum aktif melaksanakan program desa siaga, termasuk Desa Tanjung Medang yang saat sekarang dalam pembinaan pengelolaan Desa Siaga untuk menunjang program pemerintah yaitu Nusantara Sehat. Setiap Desa siaga terdapat seorang bidan desa sebagai fasilitator, dua orang penanggungjawab kader dan dua orang tokoh masyarakat dan pernah dilaksanakan pelatihan tentang desa siaga, namun masingmasing desa belum melaksanaan program desa siaga secara maksimal.

Melihat hal tersebut dan melihat kuantitas kader desa siaga yang cukup banyak yaitu 100 orang, dan di Desa Tanjung Medang berjumlah 30 orang, dimana masing-masing desa siaga tersebut belum mampu berjalan dengan aktif. Desa siaga yang kurang aktif ini dapat dilihat dari pelaksanaan kegiatan Desa Siaga seperti Survey Mawas Diri (SMD) dan Musyawarah Masyarakat Desa (MMD) yang belum rutin dilaksanakan. UKBM yang ada seperti Ambulan Desa, Dana Sehat, Kadarsi, Penyehatan Lingkungan, Pengamatan Kesehatan Berbasis Masyarakat, Arisan Jamban dan lainlain belum berjalan dengan baik (Puskesmas Rupat Utara, 2015). Menurut pengelola Program Promosi Kesehatan Puskesmas Rupat Utara, salah satu hambatan dari pelaksanaan desa siaga adalah kurangnya keaktifan kader dalam pengelolaan desa siaga sehingga pelaksanaan program desa siaga ini belum berjalan sesuai dengan harapan. Kader desa siaga hanya aktif pada kegiatan posyandu sedangkan UKBM dan kegiatan yang lain belum terlaksana dengan baik.

Berdasarkan fenomena tersebut, peneliti merasa tertarik untuk melakukan penelitian tentang Faktor-faktor yang berhubungan dengan keaktifan kader dalam pelaksanaan program Desa Siaga di Desa Tanjung Medang Wilayah Kerja Puskesmas Rupat Utara Kabupaten Bengkalis tahun 2017. 


\section{METODE PENELITIAN}

Jenis Penelitian ini adalah deskriptif analitycs dengan desain penelitian cross sectional, dimana hubungan variabel independen dengan variabel dependen dilihat dan diamati secara bersamaan (Notoatmojo, 2005). Sampel pada penelitian ini adalah Kader yang tinggal di desa Tanjung Medang wilayah Kerja Puskesmas Rupat Utara yang memenuhi kriteria inklusi sebanyak 30 orang. Pengambilan sampel menggunakan total sampling.

Adapun

prosedur

pengumpulan data, peneliti menggunakan data primer dan data sekunder. Data primer adalah data yang diperoleh langsung dari sumbernya dan dicatat oleh peneliti. Data primer dalam penelitian ini diperoleh melalui hasil kuesioner pada 30 orang kader yang berada di desa Tanjung Medang wilayah kerja Puskesmas Rupat Utara, dengan tujuan mendapatkan data kuantitatif tentang faktor Pengetahuan, Ketersediaan dana dan Dukungan masyarakat terhadap keaktifan kader dalam pelaksanaan Desa Siaga. Data sekunder adalah data yang diperoleh atau dikumpulkan peneliti dari berbagai sumber yang telah ada. Analisa data dalam penelitian ini dilakukan analisa univariat dan bivariat.

\section{HASIL PENELITIAN}

Hasil penelitian dianalisis dalam 2 bagian, yaitu analisis univariat dan bivariat. Hasil analisis univariat meliputi: distribusi frekuensi karakteristik kader, pengetahuan kader, ketersediaan dana, dukungan masyarakat yang ada atau tidaknya hubungan dengan keaktifan kader dalam pelaksanaan program Desa Siaga di Desa Tanjung edang Wilayah kerja Puskesmas Rupat Utara. Hasil analisis bivariat meliputi: pemaparan hasil uji chi square antara pengetahuan kader, ketersediaan dana dan dukungan masyarakat dengan keaktifan kader dalam pelaksanaan program Desa Siaga di Desa Tanjung Medang Wilayah kerja Puskesmas Rupat Utara. Hasil uji chi square ini dikatakan bermakna jika nilai $p$ value $<0,05$.

Berdasarkan Karakteristik Kader menunjukkan bahwa Kader dalam penelitian ini sebagian besar berjenis kelamin perempuan 24 orang (80\%), lebih dari separoh responden berusia 25-35 tahun sebanyak 25 orang $(83,33)$, sebagian besar berpendidikan SMU 21 orang (70\%) dan sebagian besar responden telah menikah 23 orang $(76,7 \%)$, sebagian besar pekerjaan responden IRT/tidak bekerja 15 responden $(50 \%)$ serta lebih dari separoh responden masa kerjanya $<1$ tahun sebanyak 20 orang $(66,7 \%)$.

Sedangkan dari hasil analisa univariat yaitu dari faktor pengetahuan kader, ketersediaan dana, dukungan masyarakat didapatkan hasil bahwa dari 30 Kader dalam penelitian ini sebagian besar berpengetahuan rendah yaitu sebanyak 21 orang $(70 \%)$, kemudian lebih dari separoh responden menyatakan bahwa adanya ketersediaan dana dalam pelaksanaan program Desa Siaga yaitu sebanyak 20 orang $(66,7 \%)$, selanjutnya dari faktor dukungan masyarakat, 
sebagian besar masyarakat tidak mendukung dengan program Desa Siaga, yaitu sebanyak 22 orang $(73,3$ $\%$ ), sedangkan dari faktor keaktifan kader, sebagian besar kader tidak aktif dalam melaksanakan program desa siaga, yaitu sebanyak 24 orang $(80 \%)$.

Selanjutnya dari hasil analisis bivariat yaitu menganalisis faktorfaktor yang berhubungan dengan keaktifan Kader dalam pelaksanaan program Desa Siaga yaitu dari faktor pengetahuan, ketersediaan dana dan dukungan masyarakat. Berdasarkan uji statistik menunjukkan bahwa ada hubungan yang signifikan antara pengetahuan kader dengan keaktifan kader dalam pelaksanaan program Desa Siaga, hal ini dapat dibuktikan dengan nilai $P$ Value $0,000 \leq 0,05$, serta dari hasil analisis juga diketahui nilai POR (Prevalence Odds Ratio) adalah 7,0 yang artinya kader yang berpengetahuan rendah memiliki peluang 7 kali untuk tidak aktif dalam pelaksanaan program Desa Siaga.

Sedangkan dari faktor ketersediaan dana sesuai dengan uji statistik Chi Square didapatkan nilai $P$ Value $0,03 \leq 0,05$ yang berarti ada hubungan yang signifikan antara ketersediaan dana dengan keaktifan kader dalam pelaksanaan program Desa Siaga, dan dari hasil analisis juga diketahui nilai POR (Prevalence Odds Ratio) adalah 0,5 yang artinya kader yang tidak ada memiliki ketersediaan dana memiliki peluang 0,5 kali untuk tidak aktif dalam pelaksanaan program Desa Siaga.

Selanjutnya dari faktor dukungan masyarakat Berdasarkan uji statistik Chi Square didapatkan nilai $P$ Value $0,010 \leq 0,05$ yang berarti ada hubungan yang signifikan antara dukungan masyarakat dengan keaktifan kader dalam pelaksanaan program Desa Siaga, dan dari hasil analisis juga diketahui nilai $P O R$ (Prevalence Odds Ratio) adalah 0,4 yang artinya kader yang tidak mendapat dukungan masyarakat memiliki peluang 0,4 kali untuk tidak aktif dalam pelaksanaan program Desa Siaga.

\section{PEMBAHASAN}

Berdasarkan hasil penelitian menunjukkan bahwa ada hubungan yang signifikan antara pengetahuan kader dengan keaktifan kader dalam pelaksanaan program Desa Siaga Hasil ini menurut asumsi peneliti, adalah faktor pengetahuan sangat berperan penting sekali seseorang berperilaku melakukan sesuatu yang sesuai dengan pengetahuannya berdasarkan tanggungjawab dan wewenang yang diberikan, dengan kata lain kader yang mempunyai pengetahuan tinggi tentang program pelaksanaan Desa Siaga, maka kader tersebut akan berusaha secara aktif melaksanakan program Desa Siaga sesuai dengan peran dan fungsinya sebagai kader Desa Siaga.

Menurut Notoatmodjo (2010) meyatakan bahwa terdapat tiga prakondisi yang dapat menumbuhkan peran serta masyarakat, salah satunya adalah mempunyai pengetahuan yang luas dan latar belakang yang memadai sehingga dapat mengidentifikasi masalah, prioritas masalah dan melihat permasalahan secara komprehensif. Notoatmodjo (2010) juga menerangkan bahwa pengetahuan adalah domain yang 
sangat penting untuk membentuk perilaku seseorang. Perilaku baru atau adopsi perilaku yang didasari oleh pengetahuan, kesadaran dan sikap yang positif, maka perilaku tersebut akan bersifat langgeng (long lasting). Sebaliknya apabila perilaku itu tidak didasari pengetahuan dan kesadaran maka perilaku tersebut tidak akan berlangsung lama.

Penelitian ini sejalan dengan penelitian yang dilakukan Soni (2007) dan Hidayati (2011) yang menyatakan ada hubungan yang bermakna antara pengetahuan dengan keaktifan kader. Kemungkinan kader yang mempunyai pengetahuan tinggi untuk aktif adalah 4 kali dari pada kader dengan pengetahuan rendah.

Sedangkan dari faktor ketersediaan dana didapatkan hasil penelitian bahwa ada hubungan yang signifikan antara ketersediaan dana dengan keaktifan kader dalam pelaksanaan program Desa Siaga Menurut asumsi peneliti berdasarkan hasil penelitian tersebut bahwa untuk terlaksananya suatu kegiatan, maka diperlukan ketersediaan dana walaupun bukan merupakan suatu hal yang utama karena walaupun dana ada tapi kemauan, motivasi dan tidak ada dukungan dari orang lain atau pihak lain, maka program kegiatan tersebut juga tidak akan terlaksana dengan baik dan maksimal. Akan tetapi walau bagaimanapun ketersediaan dana ini tetap dibutuhkan, karena kemauan dan motivasi yang tinggi untuk melaksanakan program Desa Siaga juga harus didukung oleh ketersediaan dana supaya program tersebut tidak mengalami kendala dan hambatan sehingga peran dan fungsi kader dapat terlaksana dengan baik dan tujuan dari program Desa Siaga dapat tercapai.

Menurut Adisamito (2007) menyebutkan bahwa pembiayaan kesehatan merupakan faktor yang signifikan dalam mempengaruhi kualitas kesehatan masyarakat suatu negara. Sumber pembiayaan kesehatan dapat berasal dari pemerintah, swasta dan masyarakat. Sedangkan James F.Mckenzie, Robert R. Pinger, Jerome E.Kotecki (2003) menyebutkan bahwa masyarakat sekarang ini lebih tergantung pada dana pemerintah, oleh karena itu diperlukan pengelolaan masyarakat yang lebih baik untuk memanfaatkan sumberdaya yang ada secara optimal untuk kesehatan. Uraian yang disampaikan James F. Mckenzie dkk (2003) ini sesuai dengan keadaan yang ada dilapangan sekarang ini. Konsep desa siaga berupa pemberdayaan masyarakat termasuk pemberdayaan pembiayaan kesehatan. Masyarakat cenderung menunggu bantuan dana dari pemerintah dari pada menggalang dana atau sumberdaya yang ada disekitarnya. Jaminan kesehatan oleh pemerintah menjadikan masyarakat lebih pasif dalam mengupayakan pemeliharaan kesehatannya. Dengan adanya Jaminan Pemeliharaan Kesehatan Masyarakat (JPKM) dari pemerintah dalam hal ini Departemen Kesehatan, maka dana sehat yang sebelumnya tumbuh dari bawah ini menjadi semakin hilang dari masyarakat.

Selanjutnya dari faktor dukungan masyarakat didapatkan bahwa ada hubungan yang signifikan antara dukungan masyarakat dengan 
keaktifan kader dalam pelaksanaan program Desa Siaga. Dari hasil ini peneliti berasumsi bahwa dalam melakukan program apapun harus melibatkan masyarakat sehingga mendapatkan dukungan dari masyarakat tersebut, karena tanpa dukungan masyarakat maka sebaik apapun program yang kita rencanakan akan sulit merealisasikan dengan baik. Jadi supaya kader bisa aktif dalam melaksanakan program Desa Siaga, maka sangat dibutuhkan dukungan dari masyarakat.

$\begin{array}{lrr}\text { Menurut } & \text { Snehandu } & \text { B Karr } \\ \text { dalam Notoatmojdo } & \text { (2010), } \\ \text { menerangkan bahwa } & \text { dalam }\end{array}$
berperilaku, seseorang cenderung membutuhkan dukungan dari masyarakat di sekitarnya. Tanpa adanya dukungan masyarakat, maka akan terjadi ketidaknyamanan seseorang dalam berperilaku.

Penelitian ini sejalan dengan Hidayati (2011). Peluang kader yang mendapat dukungan masyarakat adalah 3 kali untuk aktif dari pada kader yang tidak mendapat dukungan. Dukungan masyarakat dalam bentuk partisipasi aktif masyarakat dalam kegiatan desa siaga merupakan salah satu pendorong bagi terlaksananya kegiatan desa siaga (Azhar, T.N., Setiawan,E., Marhaeni, D., Hasanbasri, 2007)

\section{KESIMPULAN}

Setelah dilakukan penelitian, maka dapat disimpulkan bahwa adanya hubungan yang bermakna antara Pengetahuan Kader, Ketersediaan dana dan Dukungan Masyarakat dengan keaktifan kader dalam pelakasanaan program Desa Siaga di Desa Tanjung Medang Wilayah Kerja Puskesmas Rupat Utara Kabupaten Bengkalis.

\section{SARAN}

Berdasarkan hasil penelitian ini ada beberapa saran yang dapat peneliti sampaikan antara lain pada pihak Puskesmas diharapkan lebih maksimal lagi melakukan evaluasi terhadap pelaksanaan program Desa Siaga ini. Berdasarkan hasil temuan penelitian didapatkan pengetahuan kader $70 \%$ berada pada kategori rendah, maka dalam hal ini pihak puskesmas harus memberikan pelatihan dan workshop kepada para kader secara terstruktur dengan baik. Selanjutnya bagi pihak Desa Khususnya Kepala Desa disarankan dapat membuat kebijakan yang senantiasa mendukung dan berperan aktif dalam pelaksanaan program Desa Siaga di Desa Tanjung Medang wilayah kerja Puskesmas Rupat Utara. Begitu juga halnya bagi peneliti selanjutnya, diharapkan penelitian ini dapat menambah wawasan, pengetahuan dan pengalaman dalam melakukan Penelitian tentang faktor-faktor lain yang berhubungan dengan keaktifan kader dalam pelaksanaan program Desa Siaga. 


\section{DAFTAR PUSTAKA}

Adisasmito,Wiku.(2007). Sistem Kesehatan .Jakarta : PT Raja Grafindo Persada.

Arikunto, S. (2010). Prosedur Penelitian: Suatu Pendekatan Praktek. Jakarta: Rineka Cipta

Azhar, T.N., Setiawan,E., Marhaeni, D., Hasanbasri. (2007). Pelaksanaan Desa Siaga Percontohan di Cibatu, Purwokerto. Kebijakan dan Managemen

Bangsawan, K Merah. (2001). Faktor-Faktor yang

Berhubungan dengan Keaktifan Kader Posyandu di Wilayah Kecamatan Teluk Betung Barat Kota Bandar Lampung. Jakarta: FKM UI.

Departemen kesehatan RI. (2007). Kurikulum dan Modul Pelatihan Bidan Poskesdes dalam Pengembangan Desa Siaga. Jakarta: Depkes RI

Gibson, L.J, Ivanchevich, J.M, Donelly, J.H. (1988). Organisasi dan Managemen, Perilaku, Struktur, Proses (Edisi 4) (Djoerban Wahid, Penerjemah). Jakarta: Erlangga.

Handoko, T Hani. (1985). Managemen Personalia dan Sumber Daya Manusia. Yogyakarta: 1985.
Hidayati, Ririn. (2011). FaktorFaktor yang Berhubungan dengan Keaktifan Kader dalam Mengelola Kelurahan Siaga di Wilayah Puskesmas Janti Kodya Malang Jawa Timur. Jakarta: FKM UI.

Ilyas, Yaslis. (2002). Kinerja, Teori dan Aplikasinya. Jakarta: Pusat Kajian Ekonomi Kesehatan FKM UI.

Faktor-faktor..., Nur Farida Yohanik, (2012) Faktor-faktor yang berhubungan dengan Keaktifan Kader dalam Pengelolaan Desa Siaga di Wilayah Kerja Puskesmas TanjungAnom Kabupaten Nganjuk Provinsi Jawa Timur, FIK UI

Kementerian Kesehatan Republik Indonesia (2011). Pedoman Umum Pengembangan Desa dan Kelurahan Siaga Aktif. Jakarta.

Maulana, Heri D.J (2009). Promosi Kesehatan. Jakarta: EGC.

Promosi Kesehatan: Sebuah Pengantar Proses Belajar Mengajar dalam Pendidikan. Yogyakarta: Graha Ilmu.

Notoatmodjo, S. (2010). Etika \& Hukum Kesehatan.Jakarta: Rineka Cipta.

Nuraeni, D. (2006). Bencana dan Pelayanan Kesehatan bagi Masyarakat Indonesia. Jakarta: Pelita. 
Pusat Promosi Kesehatan. (2011). Petunjuk teknis penghitungan biaya pengembangan desa dan kelurahan siaga aktif. Jakarta. Kemenkes RI.

Puskesmas Rupat Utara. (2015). Laporan Perkembangan Desa Siaga Tahun 2015. Bengkalis.

Robbins, S.P. (1995). Teori Organisasi, Struktur, Desain dan Aplikasi (edisi ke tiga) (Jusuf Udaya, Penerjemah). Jakarta: ARCAN.

Saragih, Suriani W. (2011). FaktorFaktor yang Berhubungan dengan Partisipasi Kader Kesehatan dalam Deteksi Risiko Ibu Hamil di Puskesmas Kuta Utara Kabupaten Bandung. Jakarta: FKM UI

Sarlito, S.(2009). Pengantar Psikologi Umum: Jakarta: PT. Raja Grafindo Persada.

Siagian, Sondang P. (1989). Teori Motivasi dan Aplikasinya. Jakarta: Bina Aksara.
Sobur, A. (2003). Psikologi Umum. Bandung: Pustaka Setia.

Wardani, Dian Kusuma. (2005). Faktor-Faktor yang Berhubungan dengan Perilaku Kader dalam Fungsi Penggerakan dan Penyuluhan di Puskesmas Pesawahan Kecamatan Pesawahan Purwakarta. Jakarta: FKM UI 